\title{
Właściwości i struktura złączy spawanych stalowych belek stropowych z lat 30. XX w. ze wzmocnieniami z niestopowej stali konstrukcyjnej
}

\section{Properties and structure of welded joints of steel beams from the 1930s with non-alloy structural steel reinforcements}

\section{Streszczenie}

Wieloletnia eksploatacja lub zmiana sposobu użytkowania stalowych konstrukcji budowlanych często wymaga ich modernizacji (wzmacniania) z zastosowaniem spawania. Niezbędne jest wówczas wykonanie połączeń spawanych elementów stalowych starej stali z elementami z nowej stali. Problem ten pokazano na przykładzie badania właściwości mechanicznych i struktury złączy doczołowych i przylgowych starej i nowej stali. Wyniki tych badań można wykorzystać przy projektowaniu wzmacniania starych konstrukcji stalowych z zastosowaniem technik spawalniczych.

\section{Abstract}

Long time maintenance or change in usage of steel construction structures often requires upgrading (reinforcement) with welding technology. It is necessary to perform welded joints of the old steel elements with elements from new steel. This Problem is shown as a study of structure and mechanical properties of butt and filet joints of old and new steel. The results of these tests can be used in the design of reinforcing old steel structures using welding techniques.

\section{Wstęp}

W pierwszej połowie XX w. powstało wiele stalowych konstrukcji budowlanych. Długi okres eksploatacji spowodował, że obecne właściwości stali w wyniku procesów starzeniowych mogą znacznie różnić się od jej stanu wyjściowego. Zmiana przeznaczenia, zwiększenie obciążenia oraz zły stan techniczny tych obiektów powoduje konieczność ich modernizacji. W celu zapewnienia dalszej bezpiecznej eksploatacji dokonuje się wzmocnień konstrukcji z zastosowa-

Dr inż. Andrzej Skrzypczyk, mgr inż. Sebastian Sikora Politechnika Świętokrzyska, Kielce.
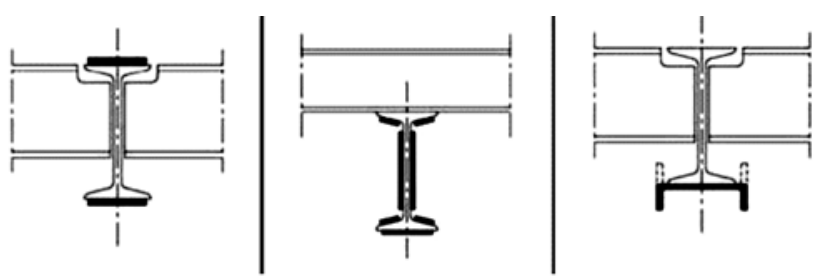

Rys. 1. Sposoby wzmacniania kształtowników stalowych [2] Fig. 1. Methods of reinforcing steel profiles [2]

niem technik spawalniczych. Często wzmacnianymi elementami konstrukcji stalowych budowlanych są różnego rodzaju belki, pracujące głównie na zginanie w jednej lub dwóch płaszczyznach [1]. Na rysunku 1 pokazano sposoby wzmacniania belek stropowych 

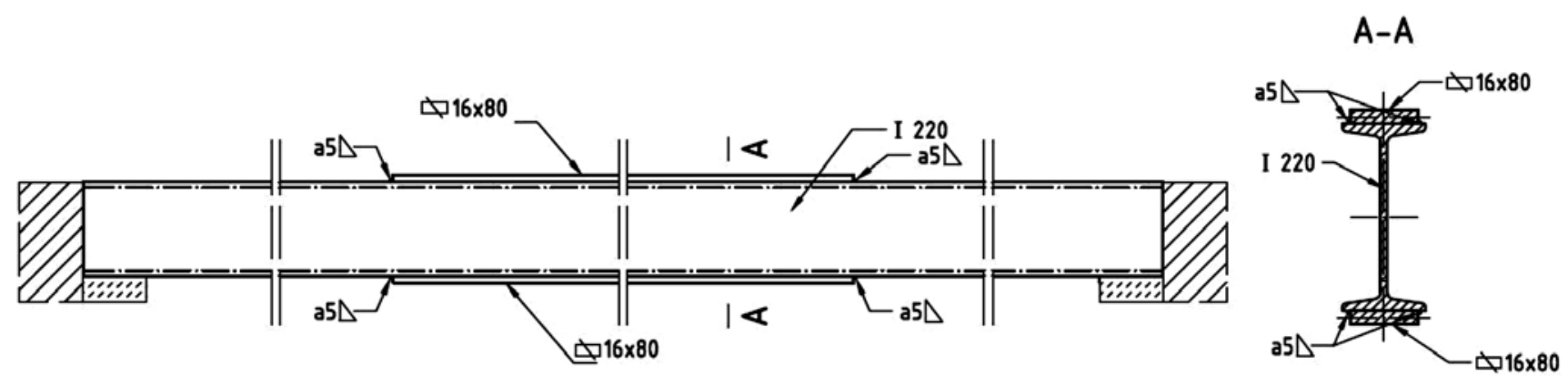

Rys. 2. Rozwiązanie konstrukcyjne wzmocnienia belki dwuteowej

Fig. 2. Design solution to strengthen I-beam

wykonanych z kształtowników stalowych przy pomocy płaskowników.

Dodanie wzmocnień można realizować w różny sposób. Najłatwiej wykonać to przez przyspawanie płaskowników. Stale ze starych konstrukcji mogą znacznie różnić się składem chemicznym, a zwłaszcza zawartością siarki i fosforu od współczesnych stali konstrukcyjnych niestopowych przeznaczonych na spawane konstrukcje stalowe. Powoduje to, że prace modernizacyjne wzmacniania starej konstrukcji stalowej muszą być poprzedzone przeprowadzoną oceną możliwości wykonania złączy spawanych starej stali z nową.

Najlepiej ocenę tą przeprowadzić (jeśli istnieje możliwość pobrania próbek ze starej konstrukcji), wykonując złącza próbne starej stali z elementem wzmocnienia wykonanym z nowej stali.

W pracy przedstawiono wyniki badań właściwości mechanicznych i struktury złączy wzmocnień belki dwuteowej wykonanej z kształtownika 1220 płaskownikami ze stali S235JR+AR o wymiarach $16 \times 80 \mathrm{~mm}$ w przekroju poprzecznym (rys. 2).

\section{Materiały użyte do badań}

Do wykonania złączy próbnych zastosowano wycinki ze starej stali o składzie chemicznym i właściwościach mechanicznych przedstawionych w tablicach I i II. W tablicach III i IV podano skład chemiczny i właściwości mechaniczne płaskowników ze stali S235JR+AR zastosowanych na elementy wzmocnień.

Jak widać $z$ tablic od I do IV skład chemiczny i właściwości tych stali różnią się dość znacznie. Równoważnik chemiczny węgla dla starej stali wynosi 0,15 , a dla nowej 0,28 .

Na rysunku 3 pokazano mikrostrukturę próbek starej stali, a na rysunku 4 mikrostrukturę stali wzmocnienia.

Tablica I. Skład chemiczny starej stali, \% wag.

Table I. The chemical composition of the old steel, wt.\%

\begin{tabular}{|c|c|c|c|c|c|c|}
\hline $\mathrm{C}$ & $\mathrm{Mn}$ & $\mathrm{Si}$ & $\mathrm{P}$ & $\mathrm{S}$ & $\mathrm{Cu}$ & $\mathrm{Cr}$ \\
\hline 0,091 & 0,260 & 0,006 & 0,0117 & 0,0195 & 0,095 & 0,025 \\
\hline $\mathrm{Ni}$ & $\mathrm{Al}$ & $\mathrm{V}$ & $\mathrm{Mo}$ & $\mathrm{Nb}$ & $\mathrm{Ti}$ & $\mathrm{Fe}$ \\
\hline 0,043 & 0,008 & 0,000 & 0,006 & 0,002 & 0,006 & reszta \\
\hline
\end{tabular}

Tablica II. Właściwości mechaniczne starej stali

Table II. Mechanical properties of old steel

\begin{tabular}{|c|c|c|}
\hline $\mathrm{R}_{\mathrm{e}}, \mathrm{MPa}$ & $\mathrm{R}_{\mathrm{m}}, \mathrm{MPa}$ & $\mathrm{A}_{5}, \%$ \\
\hline 311 & 498 & 22,8 \\
\hline
\end{tabular}

Tablica III. Skład chemiczny stali S235JR+AR, \% wag. Table III. The chemical composition of S235JR+AR steel, wt.\%

\begin{tabular}{|c|c|c|c|c|c|c|}
\hline $\mathrm{C}$ & $\mathrm{Mn}$ & $\mathrm{Si}$ & $\mathrm{P}$ & $\mathrm{S}$ & $\mathrm{Cu}$ & $\mathrm{Cr}$ \\
\hline 0,16 & 0,67 & 0,17 & 0,015 & 0,005 & 0,02 & 0,03 \\
\hline $\mathrm{Ni}$ & $\mathrm{Al}$ & $\mathrm{V}$ & $\mathrm{Mo}$ & $\mathrm{Nb}$ & $\mathrm{Ti}$ & $\mathrm{N}_{2}$ \\
\hline 0,02 & 0,028 & $<0,005$ & $<0,05$ & $<0,01$ & $<0,005$ & 0,006 \\
\hline
\end{tabular}

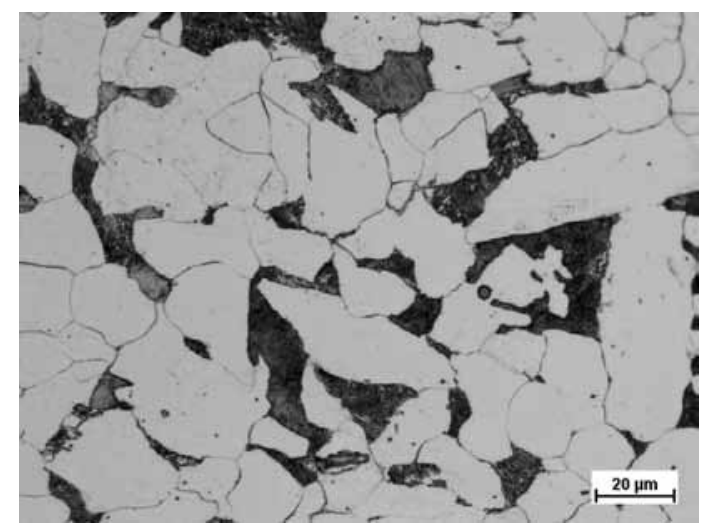

Rys. 3. Struktura starej stali

Fig. 3. Structure of old steel

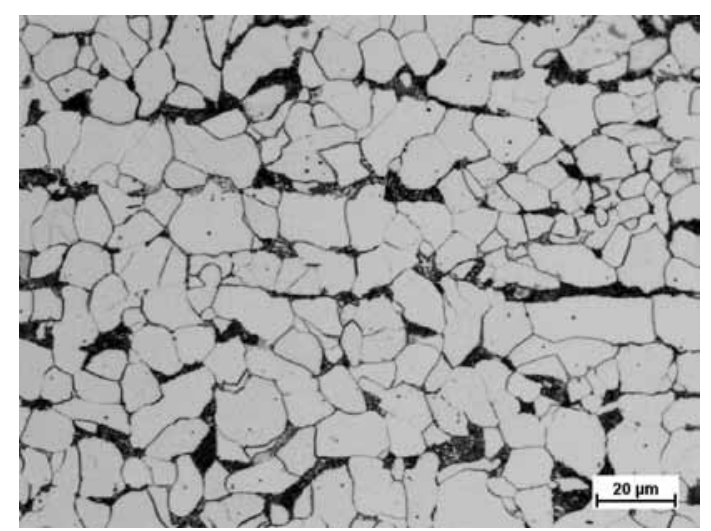

Rys. 4. Struktura stali S235JR+AR

Fig. 4. Structure of S235JR+AR steel 
Tablica IV. Właściwości mechaniczne stali S235JR+AR

Table IV. Mechanical properties of S235JR+AR steel

\begin{tabular}{|c|c|c|c|c|c|c|c|c|}
\hline $\mathrm{R}_{\mathrm{e}}, \mathrm{MPa}$ & $\mathrm{R}_{\mathrm{m}}, \mathrm{MPa}$ & $\mathrm{A}_{5}, \%$ & Typ próbki & Temp., ${ }^{\circ} \mathrm{C}$ & $\mathrm{KV}$ próba 1, J & $\mathrm{KV}$ próba 2, J & $\mathrm{KV}$ próba 3, J & $\mathrm{KV}$ śred. J \\
\hline 300 & 425 & 31 & $\mathrm{KV}$ & +20 & 205 & 181 & 176 & 95 \\
\hline
\end{tabular}

\section{Wykonanie złączy próbnych}

Do wykonania złączy próbnych zastosowano metodę MAG. Badania obejmowały wykonanie złączy przylgowych ze spoiną pachwinową oraz złączy doczołowych ze spoiną czołową jednostronną na pełny przetop. $\mathrm{W}$ tablicy $\mathrm{V}$ podano parametry technologiczne spawania złączy próbnych. Wykonanie złączy doczołowych starej stali z nową miało na celu wykonanie próbek do badań właściwości mechanicznych. Sposób realizacji przygotowania próbek i brzegów do spawania złączy doczołowych starej stali z nową pokazano na rysunkach 5 i 6 . Poszczególne próbki ustawiano, tak aby uwzględnić kierunek walco-

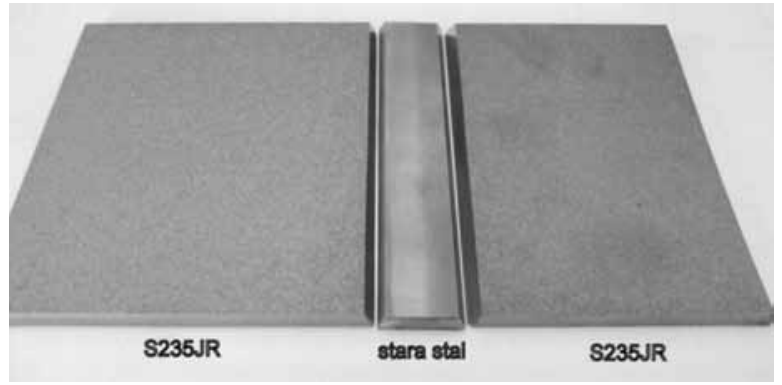

Rys. 5. Widok przygotowania próbek do spawania - statyczna próba rozciągania

Fig. 5. View of the preparation of sample for welding - static tensile test

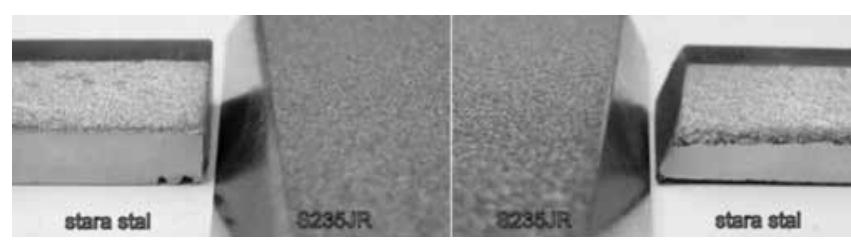

Rys. 6. Widok przygotowania próbek do spawania - próba udarności, $z$ lewej przygotowanie na $1 / 2 \mathrm{~V}, z$ prawej przygotowanie na $V$

Fig. 6. View of the preparation of sample for welding-impact test, in the left $1 / 2 \mathrm{~V}$ preparing, in the right $\mathrm{V}$ preparation

Tablica V. Parametry technologiczne spawania złączy próbnych Table V. Technological parameters of welding of test joints

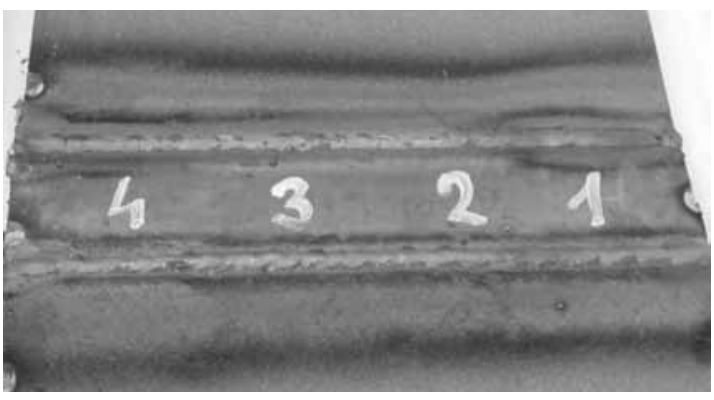

Rys. 7. Złącze próbne

Fig. 7. Welded test joint

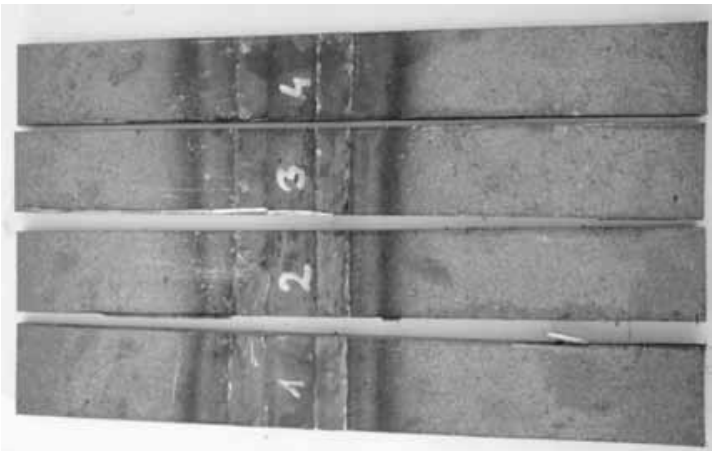

Rys. 8. Sposób pobierania próbek do badań niszczących

Fig. 8. Arrangement and method of retrieving samples for destructive testing

wania dla odcinków próbnych. Dla próbek do statycznej próby rozciągania kierunek ten był równoległy do spoiny, a dla próbek do badań udarności był prostopadły do spoiny.

Jako materiału dodatkowego użyto litego drutu elektrodowego w gatunku OK AristoRod 12.50 o oznaczeniu G3Si1 wg PN-EN ISO 14341 i dwuskładnikową mieszankę gazową M21 zgodnie z PN-EN ISO 14175, zawierającą $18 \%$ dwutlenku węgla i $82 \%$ argonu.

Przykładowe złącze próbne pokazano na rysunku 7. $Z$ tak wykonanych złączy próbnych pobrano próbki do badań niszczących (rys. 8).

\begin{tabular}{|c|c|c|c|c|c|c|}
\hline Rodzaj złącza & Ścieg & $\begin{array}{c}\text { Średnica } \\
\text { spoiwa, mm }\end{array}$ & $\begin{array}{c}\text { Natężenie } \\
\text { prądu, A }\end{array}$ & Napięcie łuku, V & $\begin{array}{l}\text { Prędkość poda- } \\
\text { wania drutu } \\
\text { m/min. }\end{array}$ & $\begin{array}{c}\text { Prędkość } \\
\text { spawania } \\
\text { cm/min }\end{array}$ \\
\hline \multirow{3}{*}{$\begin{array}{c}\text { BW } \\
\text { V }\end{array}$} & 1 & 1,2 & $146-163$ & $22-23$ & $5,0-5,5$ & $26-30$ \\
\hline & 2 & 1,2 & $182-209$ & $23-24$ & $6,0-6,5$ & $29-34$ \\
\hline & 3 & 1,2 & $257-284$ & $30-31$ & $7,5-8,2$ & $30-35$ \\
\hline \multirow{4}{*}{$\begin{array}{l}\text { BW } \\
1 / 2 \mathrm{~V}\end{array}$} & 1 & 1,2 & $141-166$ & $22-23$ & $5,0-5,5$ & $24-29$ \\
\hline & 2 & 1,2 & $175-200$ & $23-24$ & $5,9-6,4$ & $28-33$ \\
\hline & 3 & 1,2 & $261-282$ & $30-31$ & $7,5-8,2$ & $31-36$ \\
\hline & $p$ & 1,2 & 162-199 & $23-24$ & $6,2-6,7$ & $32-37$ \\
\hline
\end{tabular}



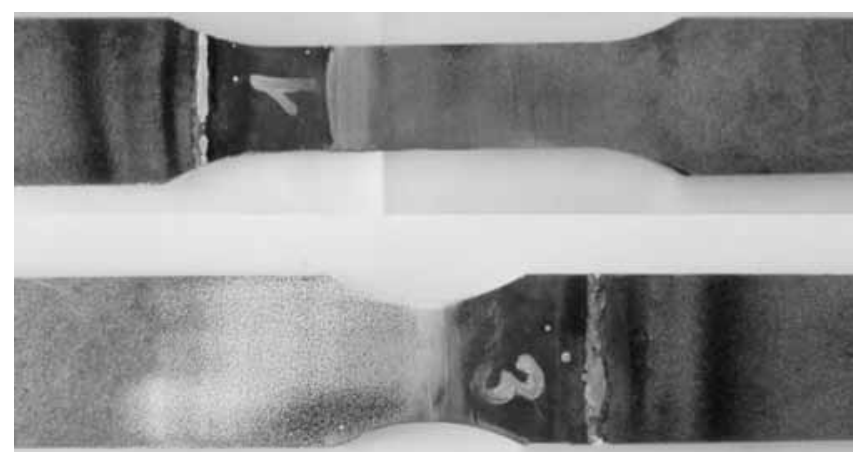

Rys. 9. Widok próbek do statycznej próby rozciągania

Fig. 9. View of samples for static tensile test

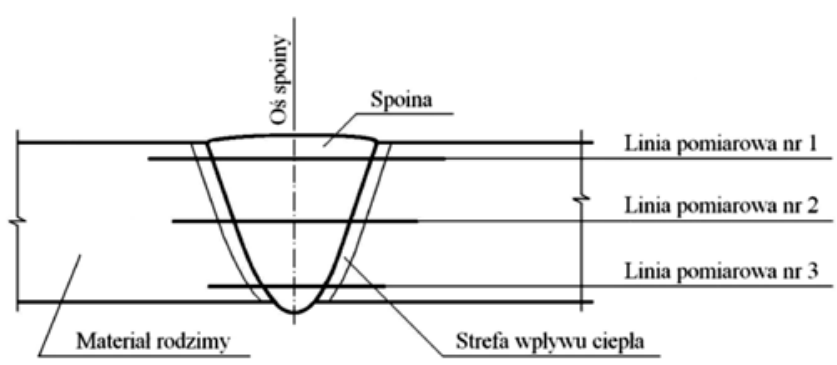

Rys. 10. Rozmieszczenie linii pomiaru rozkładu twardości

Fig. 10. Location of lines of the indentations

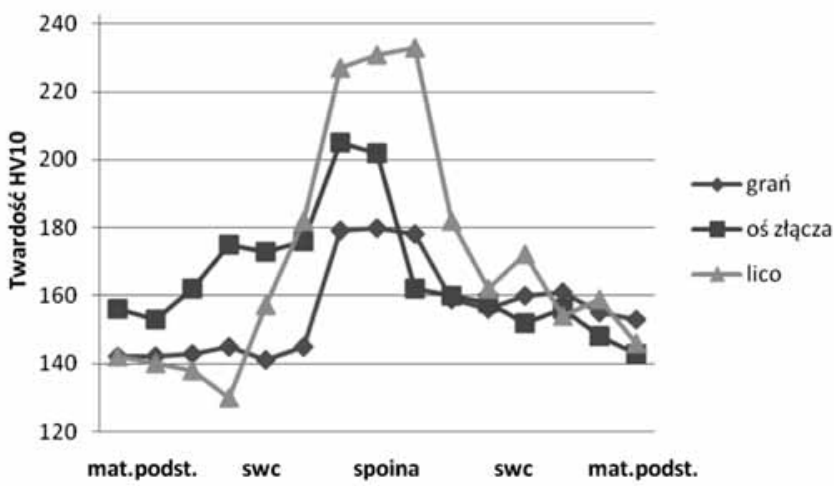

Rys. 11. Rozkład twardości w przekroju poprzecznym złącza doczołowego. Złącze V

Fig. 11. Hardness test results in the cross section of the butt weld - $V$ preparation

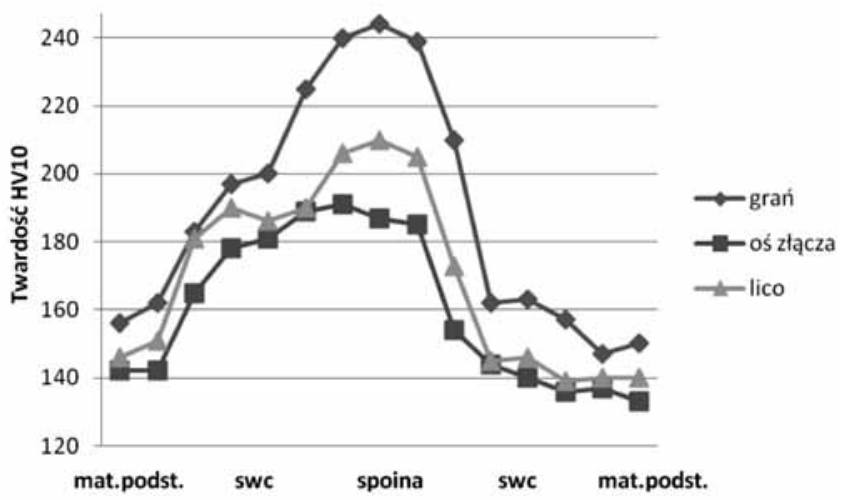

Rys. 12. Rozkład twardości w przekroju poprzecznym złącza doczołowego. Przygotowanie na $1 / 2 \mathrm{~V}$

Fig. 12. Hardness test results in the cross section of the butt weld $1 / 2 \mathrm{~V}$ preparation

\section{Badania nieniszczące}

Program badań obejmował: badania wizualne, badania ultradźwiękowe, statyczną próbę rozciągania, próbę zginania, badania twardości, badania udarności, badania struktury złączy spawanych.

Wykonane złącza próbne poddano badaniom wizualnym i ultradźwiękowym. Na podstawie tych badań stwierdzono, że złącza spawane spełniają wymagania poziomu jakości B wg PN-EN ISO 5817.

\section{Badania niszczące}

Statyczną próbę rozciągania próbek poprzecznych ze złączy spawanych wykonano zgodnie z PN-EN ISO 4136. Wykonano dwa rodzaje próbek (rys. 9). Jeden rodzaj dla oceny wytrzymałości złącza, a drugi dla zbadania wytrzymałości spoiny. Zerwanie próbki nastąpiło w materiale podstawowym starej stali. Wytrzymałość na rozciąganie wynosiła $448 \mathrm{MPa}$. W przypadku próbek do badania wytrzymałości spoiny zerwanie również miało miejsce w materiale starej stali z wynikiem $364 \mathrm{MPa}$.

Próbę zginania złączy próbnych wykonano wg PNEN ISO 5173. Wykonano próby gięcia $z$ rozciąganiem lica oraz z rozciaganiem grani spoiny z zastosowaniem trzpienia o średnicy $40 \mathrm{~mm}$. W obydwóch przypadkach kąt gięcia wynosił 1800 .

Badania rozkładu twardości wykonano metodą Vickersa z obciążeniem $98 \mathrm{~N}$ na próbkach pobranych z przekroju poprzecznego złączy. Rozmieszczenie linii pomiarowych pokazano na rysunku 10 . Wyniki pomiarów twardości przedstawiono na rysunkach 11 i 12.

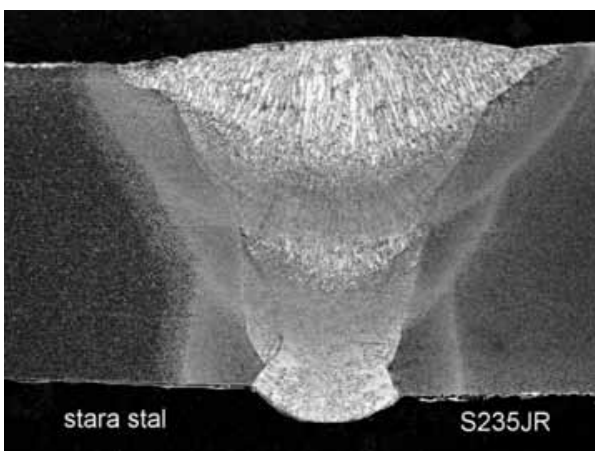

Rys. 13. Makrostruktura złącza doczołowego - przygotowanie na $V$ Fig. 13. Macrostructure of butt weld $-V$ preparation

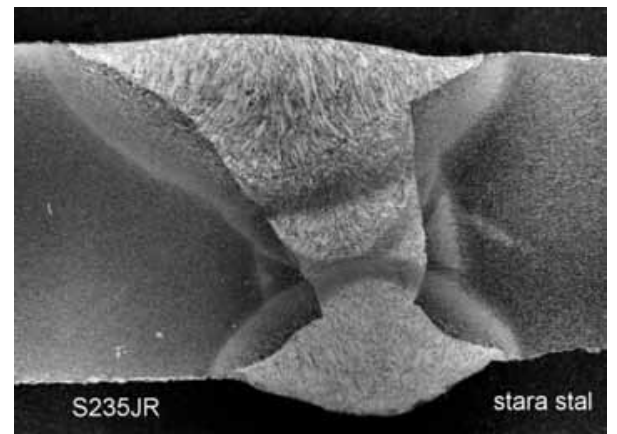

Rys. 14. Makrostruktura złącza doczołowego - przygotowanie na $1 / 2 \mathrm{~V}$ Fig. 14. Macrostructure of butt weld $-1 / 2 \mathrm{~V}$ preparation 
Badania udarności przeprowadzono na próbkach z karbem naciętym w osi spoiny (VWT) i w strefie wpływu ciepła w odległości $1 \mathrm{~mm}$ od linii wtopienia (VHT) zgodnie z PN-EN ISO 9016. Badania wykonano w temperaturze otoczenia. Udarność spoiny wynosiła 254 J, a strefy wpływu ciepła 92 J.

\section{Badania metalograficzne}

Na rysunkach $13 \div 14$ pokazano makrostruktury złączy próbnych w przekroju poprzecznym. Charakteryzują się one poprawną budową, bez niezgodności spawalniczych. Na rysunku 15 przedstawiono charakterystyczny kierunek narastania kryształów słupkowych przeciwny do kierunku odprowadzania ciepła. Spoiny charakteryzują się poprawnym wtopieniem $w$ elementy ze stali starej i nowej. Na rysunkach $16 \div 24$ przedstawiono charakterystyczne mikrostruktury dla wybranych obszarów złącza doczołowego ze spoiną czołową.

Dla spoiny czołowej wielowarstwowej charakterystyczna jest struktura ferrytyczna z obszarami gruboziarnistymi z wyraźnie zaznaczonymi kryształami słupkowymi i obszary o strukturze drobnoziarnistej uzyskane w wyniku oddziaływania cyklu cieplnego następnej warstwy.

Bezpośrednio do linii wtopienia przylega odcinek gruboziarnisty strefy wpływu ciepła (rys. 16, 18) z charakterystyczną budową iglastą w układzie Widmanstaettena. Za odcinkiem przegrzania w strefie wpływu ciepła występuje struktura drobnoziarnista charakterystyczna dla obszaru normalizacji (rys. 21, 22). Strefa wpływu ciepła kończy się obszarem niepełnego przekrystalizowania. Widać różnice $\mathrm{w}$ budowie mikrostruktury dla analogicznych obszarów SWC dla materiału starej i nowej stali.

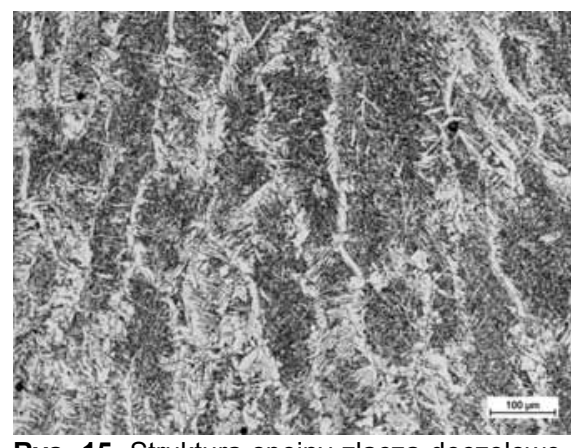

Rys. 15. Struktura spoiny złącza doczołowego

Fig. 15. Weld metal structure of the butt weld

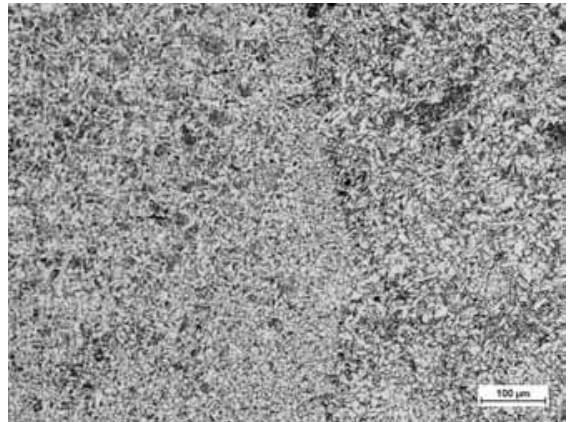

Rys. 17. Struktura w obszarze linii wtopienia złącza doczołowego - obszar normalizowany kolejnym ściegiem

Fig. 17. Structure of fusion zone of butt weld - anneal zone by next layer

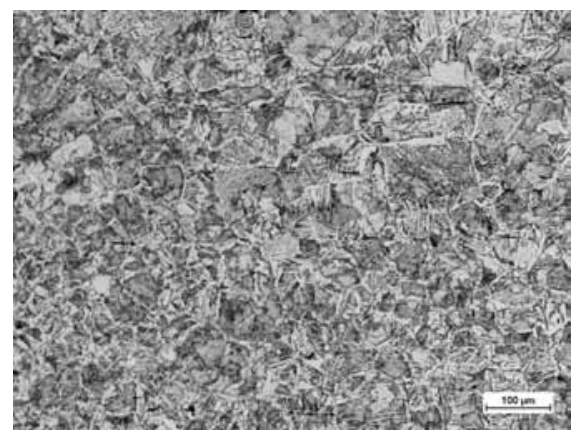

Rys. 19. Struktura swc obszaru gruboziarnistego złącza doczołowego - stara stal

Fig. 19. Structure of coarse-grained HAZ of butt weld - old steel

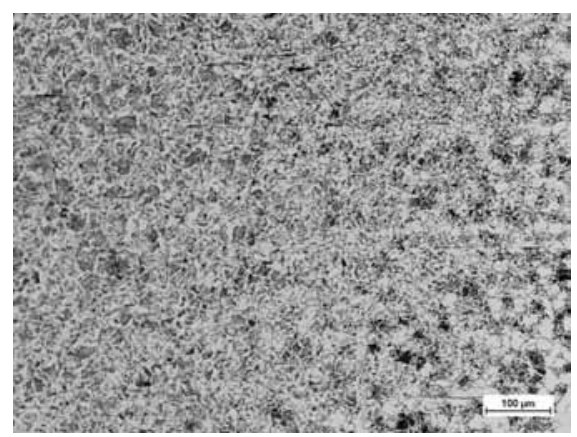

Rys. 21. Struktura swc obszaru normalizacji złącza doczołowego - stara stal

Fig. 21. Structure of fine grained $H A Z$ of butt weld - old steel

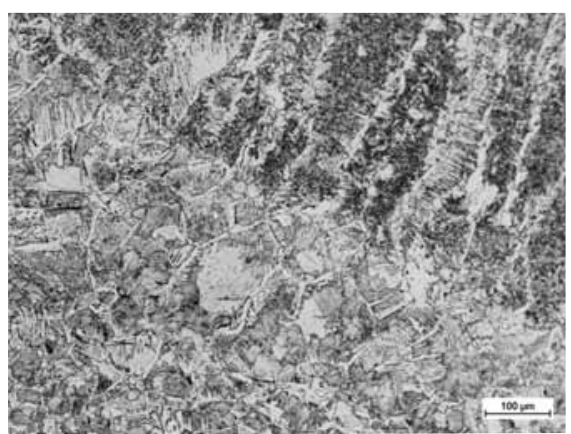

Rys. 16. Struktura w obszarze linii wtopienia złącza doczołowego - stara stal

Fig. 16. Structure of fusion zone of butt weld - old steel

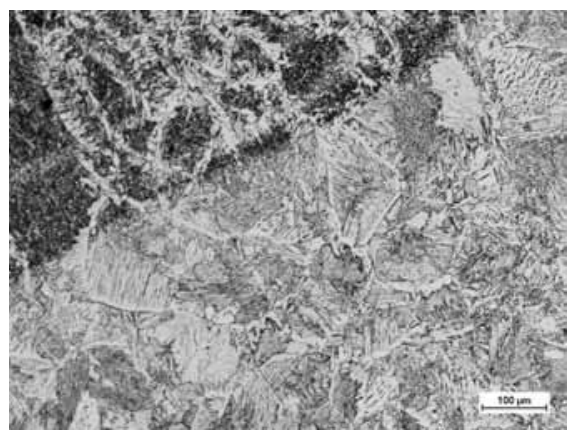

Rys. 18. Struktura w obszarze linii wtopienia złącza doczołowego- S235JR

Fig. 18. Structure of fusion zone of butt weld - S235JR steel

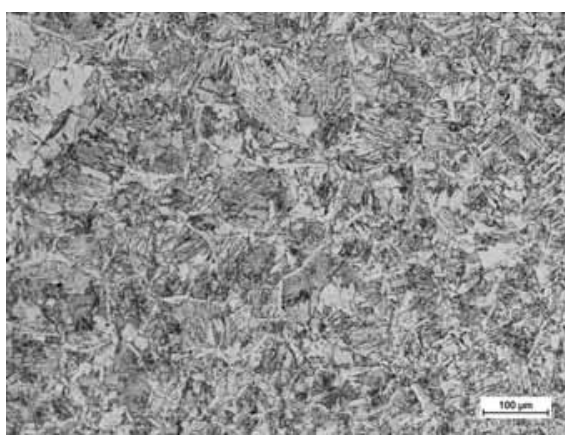

Rys. 20. Struktura swc obszaru gruboziarnistego złącza doczołowego - S235JR

Fig. 20. Structure of coarse grained HAZ of butt weld - S235JR steel

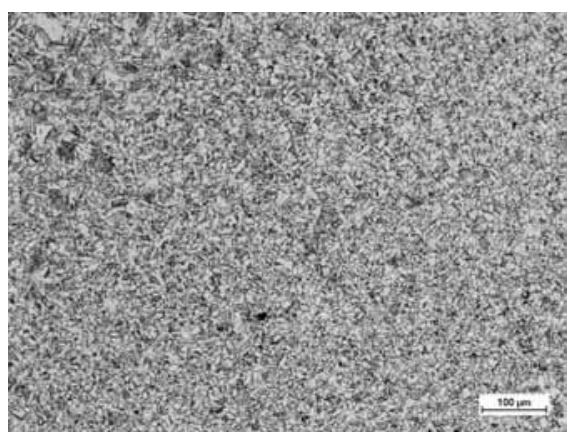

Rys. 22. Struktura swc obszaru normalizacji złącza doczołowego - S235JR

Fig. 22. Structure of fine grained $H A Z$ of butt weld - S235JR steel 


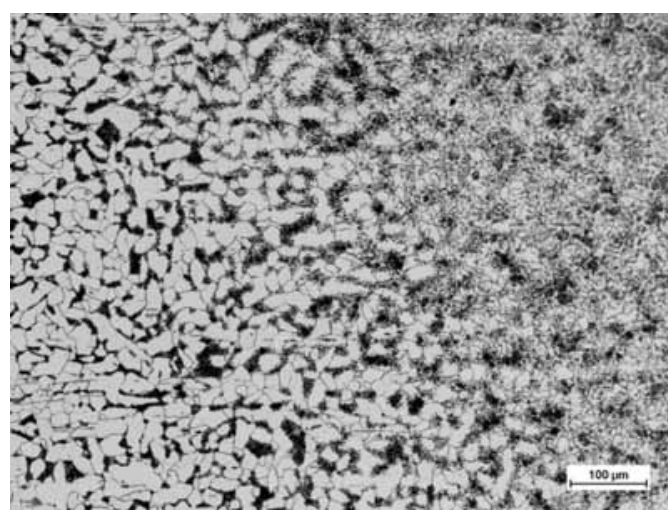

Rys. 23. Struktura swc obszaru częściowego przekrystalizowania złącza doczołowego - stara stal

Fig. 23. Structure of intercritical HAZ of butt weld - old steel

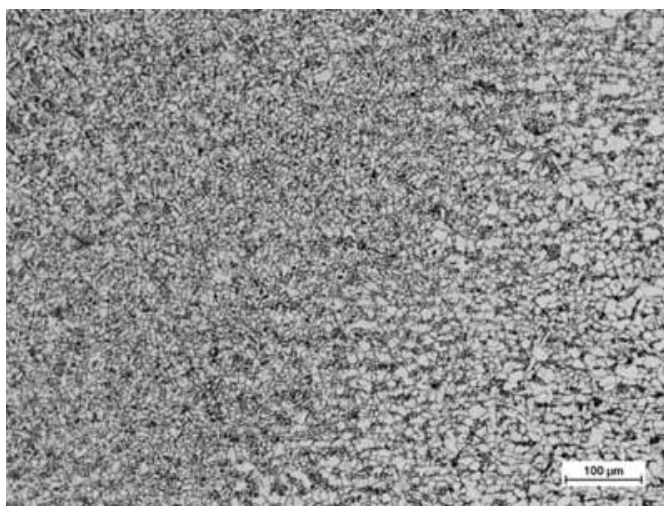

Rys. 24. Struktura swc obszaru częściowego przekrystalizowania złącza doczołowego - S235JR

Fig. 24. Structure of intercritical HAZ of butt weld - S235JR steel

\section{Wnioski}

Celem pracy była ocen właściwości i struktury złączy spawanych belek stropowych z lat 30 . ze wzmocnieniami ze stali w gatunku S235JR+AR. W wyniku przeprowadzonych prób spawania metodą MAG potwierdzono możliwość zastosowania spawania do wzmacniania starych konstrukcji stalowych.

$\mathrm{Na}$ podstawie wykonanych badań właściwości mechanicznych i struktury można wnioskować o poprawności wyboru sposobu spawania i jego parametrów technologicznych.

Przedstawione w pracy badania wytrzymałości na rozciąganie i technologiczna próba zginania złączy potwierdzają zadawalające właściwości wytrzymałościowe i plastyczne wykonanych złączy spawanych starej stali z nową.
Udarność strefy wpływu ciepła badanych złączy od strony starej stali jest znacznie mniejsza niż udarność spoiny, ale spełnia wymagania dla współczesnej stali S235JR. Badania rozkładu twardości w złączach spawanych wskazują, że zastosowane parametry technologiczne spawania nie powodują znacznego utwardzenia strefy wpływu ciepła i odzwierciedlają różnice $\mathrm{w}$ budowie strukturalnej poszczególnych obszarów złączy.

Badania strukturalne potwierdzają prawidłową budowę złączy, wolną od niezgodności spawalniczych. Dla poszczególnych obszarów złączy zarówno od strony nowej jak i starej stali charakterystyczne są struktury dla połączeń ze stali konstrukcyjnych niestopowych.

\section{Literatura}

[1] Kuśnierek M., Maciejak M.: Metody wzmacniania konstrukcji stalowych. Koło Naukowe KONKRET przy Katedrze Konstrukcji Betonowych, Politechnika Wrocławska, 2011.

[2] http://www.constructalia.com (05.08.2013)

[3] Wichtowski B., Hołowaty J.: Analiza starych mostów kolejowych według badań twardości i składu chemicznego. Materiały Konferencyjne XXV Konferencji Naukowo-Technicznej, Międzyzdroje 2011.

[4] Ricker D.T.: Field Welding to Existing Steel Structures. Engineering Journal, American Institute of Steel Construction, 1988.
[5] Carrato J.L.: Should Welding Be Used to repair Structural Steel. Conference Proceedings, 1999.

[6] PN-EN ISO 5817: Spawanie - Złącza spawane ze stali, niklu, tytanu i ich stopów (z wyjątkiem spawanych wiązką) - Poziomy jakości według niezgodności spawalniczych.

[7] PN-EN ISO 4136: Badania niszczące złączy spawanych metali - Próba rozciągania próbek poprzecznych.

[8] PN-EN ISO 5173: Badania niszczące spoin w materiałach metalowych - Badanie na zginanie.

[9] PN-EN ISO 9016: Badania niszczące złączy spawanych metali - Badanie udarności - Usytuowanie próbek, kierunek karbu i badanie. 